\title{
The Effectiveness of REBIT to Reduce Academic Cheating On Elementary School
}

\author{
Machmudah, N.R. Saleh \\ Universitas Nahdlatul Ulama \\ Surabaya, Indonesia \\ machmudah@unusa.ac.id
}

\begin{abstract}
The purpose of this study is to know the effectiveness of Rational Emotive Behavior Intervention in reducing academic cheating behavior on elementary school students in Mardisiwi Surabaya. The subjects of this study were twelve students aged 10-12 years who had medium to high grade cheating behavior. The data instrument used is the scale of cheat behavior. It is analyzed by using Wilcoxon Signed-Rank Test to know the difference between pre test and post test scores. The results showed that $p$ value $=0.017(\mathbf{p} \leq \mathbf{0 . 0 5})$. It means that, giving Rational Emotive Behavioral interventions is an effective way of reducing academic cheating behavior in grade $V$ and VI of primary students.
\end{abstract}

Keywords-rational emotive behavior therapy; academic cheating

\section{INTRODUCTION}

The goal of Indonesia's national education is to educate the nation's life and develop the Indonesian citizens as a whole. In this case, they are educated to grow into faithful and sincere men to God Almighty, have honorable character, possess knowledge and skills, get physical and spiritual health, become steady and have independent personality and nationality. A noble purpose of the Indonesian education is designed to achieve those goals.

Various efforts are applied to get a truly positive generation. However, it is not an easy job. In this case, students intend to do negative activity, such as; cheating, copying friend's work, or imitating the textbook as if it is a daily occurrence which cannot be avoided [19]. Furthermore, Fajar (2016) stated that fraud in elementary school frequently happens in which the package examination is still using a manual package system and not computer-based. Moreover, the average teacher of elementary school is still very easy to be influenced by the policy named prestige over school status "we are bad but the score of the School Exam should be higher than other schools". In contrast, the daily learning process doesn't meet the criteria of teaching, so they prefer prepare well for national examination score and every matter in terms of graduation result. Mukid and Guswina (2015) explained that the fraud during the National Examinations observed by inde- pendent monitors and National supervisors was quite disappointing. $42 \%$ of the regions have a $21 \%-90 \%$ cheating rate during the National Examination [17]. Furthermore, 39.99\% of the area cheated almost $90 \%-100 \%$ during the exam, while $17 \%$ of the area is not found any examination fraud.

McCabe (2010) explained that these cheatingulent behaviors can be found with greater quantity and frequency in the form of cheating during exams, as well as tracing on home tasks [15]. Purnamasari (2013) stated that cheating emerges as an interaction from various factors, both internal and external [18]. Baird (Purnamasari,2013) described external factors including seating sequences, important tests, difficulty level tests, unfair tests, scheduling and supervision [18]. Meanwhile, internal factors include laziness, lack of awareness of fellow students, low quality, previous failure experience, uncertain success expectation, and low self-esteem. These factors have a role to play cheating behavior that appears in students in the learning process. Sujana and Wulan (2004) explained that the inner strength is a major and very important factor that drives a person to do something [20]. In addition, Alhadza (2004) explained that this internal power will affect their mind so that it will subsequently affect students' behavior to cheat [1]. Experts believe that cheating behavior is influenced by the internal conditions of individuals; such as ratios, flavors, and behaviors. Ellis (Corey, 2010) explained that humans are essentially unique and have a rational and irrational thinking tendency [4]. Jones (2010) explained that there are various causes of why students are conditioned by irrational thinking; namely, avoid rejection, lack of understanding on what is done, have no skills, and lack of confidence.

Sujana and Wulan further explained that self-assurance plays an important role in determining individual behavior. The maladaptive or wrong way of thinking often encourages students to think and behave maladaptive/irrational. Jones (2010) explained that people tend to continue to make them disturbed because they are not able to think scientifically about what is happening in the world. However, many people continue creating their own emotional distress by not developing and using their capacity to make irrational choices. 
To minimize the irrational behavior of the students, treatment is required that may alter the irrational view of the students. Ellis (2009) explained that self-defeating ways may be able to provide short-term results for changes in human thinking. This can also be done in various ways. Ellis (Jones, 2010) stated that to change the irrational beliefs, it is necessary to take action against the self by disposing the irrational thought. Disputing (D) itself is one of the basic concepts of Rational Emotive Behavior Therapy (REBIT) theory. According to Lelono (Astuti, 2012), REBIT is a therapeutic method that uses cognitive and behavioral approaches to understand and overcome negative emotional and behavioral problems stemming from irrational beliefs. The basic concept of REBIT therapy consists of four points, consisting of A - B - C - D. Concept $\mathrm{A}$ is an antecedent event, an unpleasant experience that happened in the past. B is a belief, one's beliefs or selfbeliefs about judgment. Emotional Consequence or $\mathrm{C}$ is the result of consequences arising from a person's belief or B. Meanwhile D is a dispute or resistance commonly practiced by a therapist to change the subject's irrational thinking. D is the application of scientific methods to help clients challenge irrational beliefs that have caused emotional and behavioral disorders. Ellis (Corey, 2010) explained that D is logical principles which can be taught. These principles can be used to destroy unrealistic and irrational hypotheses which cannot be verified. Ellis (Corey, 2010) explained that humans are essentially unique and have rational and irrational thinking tendency. Ellis has a desire to change the irrational behavior of the individual and influence him to accept rational considerations (Boree, 2013). It reminds the main purpose of REBIT, which helps to minimize the self-defeating views of clients and helps clients to acquire a realistic and positive philosophy of life [4]. Therefore, in this study the researchers tried to apply REBIT method as REB Training to the behavior of academic cheating on elementary students of Mardisiwi Surabaya.

Based on the above description, the hypothesis proposed in this research is that there is an influence of rational emotive behavior intervention to the decrease academic cheating on elementary students of Mardisiwi Surabaya.

\section{METHOD}

The research design used in this research is quasi experiment because not all variables (symptoms that appear) and experimental conditions can be arranged and controlled closely. This study aims to reduce the behavior of academic cheating on elementary students of Mardisiwi Surabaya.

The populations involved in this study are students on grade V and VI at SD Mardisiwi Surabaya. There are 4 classes, in which two of them have been selected since they are compatible with the sample characteristics of the study. The sampling technique in this study is using purposive sampling because the method of sampling is in accordance with the desired criteria [11]. Technically, the sample selection is done by asking a total of 75 students drawn from two classes to find out their academic cheating behavior. In this case, teachers helped by researchers seek students who categorized as average to high academic cheater. From the results of the pilot study, participants who were given intervention were 12 students (experimental group). Once, the participants are selected according to the criteria, the researcher gives a willingness to follow the Intervention (Informed Concent) with a view to know the commitment of participants to participate in the Rational Emotive Behavior intervention program. Farikoh (2014) conducted a study to find the level of academic cheating done between boys and girls students [8]. The scale of academic cheating raises the level of the students' cheating. It is prepared by the researchers through modifying [8]. The academic aspects of academic behavior used in this research are the aspects based on Lambert, Hogan, and Barton (2003) which consist of (a) unauthorized tools and materials at the exam [10]. (B) Fabricate information, references, and results. (C) Fascinating other students to commit cheating at the exam. (D) Plagiarism. The test of the measuring instrument conducted on 75 students is done by using Alpha reliability coefficient technique, and obtained reliability coefficient (r) of 0,697. When the score obtained by the subject is high, it indicates that the level of cheating done by the student is high. Meanwhile, if the score of cheating on the students is low, then it can be admitted that the academic cheating acts on the students tend to be low. The scores were obtained based on scale distribution through pretest and post test to determine the effect of Rational Emotive Behavioral Interventions. The measurement tool used in this study modified through academicdimensional scale from the academic cheating scale.

Rational Emotive Behavioral Interventions are Interventions dedicated to express thoughts or ideas that are not logical (intelligent) person. This intervention aims to help participants discover their irrational thoughts and be able to disagree or debate these irrational thoughts into rational one. This training is expected to help convert irrational thoughts, behaviors, and emotions into racial. The modules used in this Intervention refer to [3]. According to Austad, there are three stages of treatment in emotional behavioral counseling, namely; helping participants recognize their irrational thoughts, convincing themselves that irrational thinking can be debated or disputed, and helping participants to apply disputing to themselves to make irrational thinking becomes a more rational and logical thought. This exercise needs three days which is divided into 10 series of Intervention sessions. 
The data obtained based on the field of behavioral scale cheat in the form of quantitative data. It is analyzed by using SPSS (Statisticical Social Science). Scores were obtained by counting the participants' pre-posttest. The data analysis method used in this study is in the form of non-parametric method, ie Wilcoxon Signed-Rank Test. It is used because of the small sample size so that the sampling distribution is not nearly normal [21]. The process of data analysis used SPSS version 21 for windows.

\section{RESULT AND DISCUSSION}

The rule used is, if the value of $\mathrm{p}<0.05$, then there is a significant difference, but if the value $p>0.05$ then there is no significant difference. Based on the analysis with the Wilcoon Signed-Rank Test technique, it can be seen that the post test group score of the experiments obtained from the processing stage is $\mathrm{p}=0.017(\mathrm{p}<0.05)$. These results showed that there is no significant difference between the pretest and post test values of the experimental group. In other words there is no decrease in academic cheating behavior done by students after being given the Rational Emotive Behavioral Intervention.

\section{TABLE I. RESUlts OF WILCOXON SigNED - RANK TEST ANALYSIS}

\begin{tabular}{|l|c|l|l|}
\hline Sumber & $\mathrm{Z}$ & $\mathrm{P}(2$ tailed $)$ & Keterangan \\
\hline Pre-Post Test & 2,907 & 0,017 & Significant \\
\hline
\end{tabular}

Nevertheless, the mean value of descriptive result on statistical data in pre test is (25.80) while the mean value of post test is (36.20), then the difference of nial mean rank is 10.4 . This means that the level of academic cheating behavior in students before Intervention is higher than after intervention. This difference in score shows significant differences between pre test and post test results. The existence of this significant difference indicates that the Rational Emotive Behavioral Intervention can help to decrease the students' academic cheating behavior in the Mardisiwi Elementary School. This at once confirms that the research hypothesis is accepted.

Yadev (2011) explained that the age of 10-12 is a transition from childhood to adolescence so that emotional, cognitive and behavioral changes affect their personal well-being, but it is very effective for moral planting [22]. Diener (1984) described the cognitive, emotional, and behavioral changes that are part of the stage of development occurs in adolescents [5]. In addition, there are also various changes in the individual that lead to the change of attitudes and behaviors into maladaptive.

Hurlock (2003) explained that there is a change in adolescence that creates doubt, a feeling of disbelief in ability, and insecurity. In some cases it leads to the emergence of negative attitudes and behavior of adolescents. Therefore, researchers try to develop Rational Emotive Behavior Interventions that are expected to manage maladaptive behavior and attitudes in students. The reason why the researcher choses the above Intervention as a method of intervention is to see and be aware of the REBIT function that is capable to be applied in various treatment moments.

Ellis (Latipun, 2011) explained that the REBIT-based on the Rational Emotive Behavioral Model-can be applied in a various counseling; including individual and group counseling, short therapy, family therapy, and sex therapy. Ellis (Jones, 2011) stated that REBIT is significantly effective for clients who experience anxiety at average levels, neurotic disorders, character disorders, psychosomatic problems, inability in interpersonal relationships, marital problems, parenting skills, addiction, and sexual dysfunction. Therefore, Rational Emotive Behavioral Interventions are expected to help teachers in reducing students' academic cheating behavior.

Based on the results of interventions that have been conducted, it is clear that the intervention is effective to reduce the behavior of academic cheating on elementary students of Mardisiwi Surabaya. The acceptance of hypotheses in this study is influenced by various causes. One of them is the role of REBIT the researcher chooses as an interventive method used to decrease the maladaptive behavior of the participants. This happens because in the process of research, the researchers modify the method of psychotherapy REBIT become the method of Emotive Rational Behavioral Intervention as an intervention in reducing students' academic cheating behavior. The reason is, the researcher considered that Rational Emotive Behavioral Intervention is more efficient and effective. In this case, one set of interventions can be changed by thinking, feeling, and behavior for 12 students at a time. Therefore, this modification is as a treatment to decrease the behavior of academic cheating on the students.

However, as it is known, Rational Emotive Behavior Therapy (REBIT) itself is one method of psychotherapy aimed at transforming irregular or maladaptive thinking and behavior into rational and positive thinking and behavior. Lestari (2013) explained that REBIT is a therapy that emphasized a profound change in thinking to produce meaningful change in how to feel and behave. Astuti (2012) in his research found that REBIT is a counseling therapy used to manage maladaptive problems that focus on converting irrational beliefs into rational and productive beliefs, hope that students change their individual bad habits [2]. Ellis (Jones, 2011) explained that REBIT is an active, structured-therapy that focuses on helping clients not only to feel better, but also by changing their thinking and behavior to be better. 
Therefore, it can be concluded that the REBIT method has good efficiency and effectiveness if it has to be modified as a treatment in order to decrease the behavior of academic cheating on students of grade V and VI in SD Mardisiwi Surabaya.

\section{CONCLUSION}

Based on the results of the statistical analysis performed, there was a difference that occurred in the participants after the Rational Emotive Intervention applied. This is seen from the results of the score of pretest and posttest on subjects who are members of the Rational Emotive Behavioral Intervention program. Thus, it can be concluded that the Rational Emotive Behavioral Intervention is effective in reducing academic cheating behavior among Mardisiwi elementary students in Surabaya.

Based on the results of this study, the researchers provide advice and input to the next researcher who took research with a similar theme :

The next researcher may increase the number of Intervention subjects in the study, so it will be clearer the difference between before and after treatment given in Intervention sessions.

In addition, the next researcher takes into account the timing of the execution. The time which is chosen should be more appropriate, so that the selected participants can attend the Intervention as a whole and it is better to ensure the commitment of the Intervention participants to avoid mortality.

Group interactions within the Interventions should also be enhanced so that the self-understanding process and others can work well; avoid selecting subjects with other disorders in order to the Intervention can be done optimally.

Treatment used in the Intervention can use group therapy methods that have more intense interactions with each participant, and may alter the irrational thinking of the participants.

Interventions should not only be a doctrinal process through the provision of materials, but also make the Intervention process becomes a fun process to build the participant's interest in following the intervention optimally.

\section{REFERENCES}

[1] A. Alhadza, The problem of cheating in education. Available in hhtp: // www. Bsi. Ac.id/ modules. Php [2004].

[2] D. Astuti, "Rational Emotive Behavioral Therapy as an effort to improve the quality of life of diabetes mellitus sufferers," Thesis, Yogyakarta: Post graduate Program of Faculty of Psychology and Social Sciences of the Islamic University of Indonesia, 2012.

[3] C.S. Austad, Counseling and psychotherapy today: Theory, 2009.

[4] G.Corey, Theory and practice of counseling and psychotherapy, Bandung: Refika Aditama, 2010.

[5] E. Diener, Subjective Well Being, 1984.

[6] Psychological Bulletin. 95 (3), 542- 575

[7] A. Ellis, Rational Emotive Behavioral Therapy for addiction, New York: Psycotherapy.Net, 2009.

[8] Farikoh, Analysis of the influence of the personality of Ihsan towards the tendency of acade of cheating behavior in UIN Sunan Kalijaga University's education program students. Essay, Yogyakarta: UIN Sunan Kalijaga Faculty of Social Sciences and Humeids, 2014.

[9] R.N. Jones, Theory and practice of counseling and therapy, Yogyakarta: Student Literature, 2011.

[10] E.G. Lambert, N.L. Hogan, and S.M. Barton, Collegiate academic dishonesty revised: What have they done, how often have they done it, who does Ii, and why did they do it ?. Electronics Journal Of Sociology. (On line) . Source: hhtp // www.Sociology.org/conten/ vol 7.4 / lambert etal. Html Retrieved on 27 March 2016, 2003.

[11] Latipun, Experimental psychology, 2010.

[12] Latipun, Counseling psychology, Malang: UNM Press, 2011.

[13] H. S. Lestari, Rational Emotive Behavior Therapy to treat depressive disorders, Journal of Science and Practice of Psychology, 2013.

[14] 110-114. Yogya: Megister Psychology of UGM.

[15] D.L. McCabe, Poor work ethics risk future of U.S. Business. Education and Ultimately Freedom. Rutgers Business School Newar And New Brinswik. Downloaded, 2010.

[16] February 2016 from source: www. Businnes. Rutgers.edu/ tags / 332 / page $=1$.

[17] M.A. Mukid, and N. Guswina, Estimation of the Proportion of Junior High School Students in Semarang City Being Fraudulent During the National Final Exam In 2011. Proceedings of the National Seminar of Diponegoro University Statistics, 2015.

[18] Purnamasari, "Factors affecting academic fraud in students," Educational Psychology Journal, 2013.

[19] M. Samani and Hariyanto. The concept and model of character education, Bandung: Teens Rosdakarya, 2012.

[20] I. B. Sujana and R.Wulan, The relationship between the internal control center and the intention is cheating. Journal of Psychology. 21 (), 1 - 8. Yogyakarta: Faculty of Psychology Universitas Gajah Mada, 2004.

[21] M.N. Suseno, Statistics: Theory and application for research Social Sciences and Humanities, Yogyakarta: Ash - Shaff, 2012.

[22] G. Yadev, "A study of subjectively well-being and psychological wellbeing in relation to male and female adilescents," International reffered research journal, 2011. 